\title{
E-Learning in India: Wheel of Change
}

\author{
Arun Gaikwad ${ }^{1}$, Vrishali Surndra Randhir ${ }^{2 *}$ \\ 1 S.N. Arts, DJM Commerce, BNS College Sangamner, Pune, Maharashtra, India. \\ 2 Ness Wadia College of Commerce, Pune, Maharashtra, India. \\ * Corresponding author. Tel.: +919850852020; email: vrishalirandhir@Yahoo.co.in \\ Manuscript submitted August 21, 2015; accepted December 15, 2015. \\ doi: 10.17706/ijeeee.2016.6.1.40-45
}

\begin{abstract}
E-learning activities are important for the development of any country. In modern era everybody is thinking about growth and Educational development. If it is planned properly then proper results will come. In this research paper development through E-learning in India is observed. If it planned properly then proper results will be affecting positively. In this research paper, we observed that E-learning is an effective tool for development of educational sector in India. E-learning is learning, utilizing electronic technologies to access educational curriculum outside of a traditional classroom. In most cases, it refers to a course, program or degree delivered completely online. The basic objective of this research paper is to understand concept of e-learning and to examine the type of e-learning. It also summarizes several opinions regarding the comparison between traditional learning and modern learning technique. The modern method in teaching and learning are useful for development of education sector in Indian context. The research paper focused on classroom learning and e-learning in India as a main wheel of development of education.
\end{abstract}

Key words: Education, educational development, e-learning, formal e-learning, informal e-learning.

\section{Introduction}

The e-learning activities are important for the development of any country. In modern era everybody is thinking about growth. If it is planned properly then proper results comes. In this research paper through E-learning in India is observed. The research paper focused on classroom learning and E-Learning in India as a main wheel of development of education. Soon after independence in 1947, the Govt. of India had the challenge of bringing uniformity in educational system and providing education to large segments of the population [1]. Due to various schemes undertaken by India to improve the literacy rate. These measured have resulted in increase in literacy rate from $65.38 \%$ in 2001 to $74.04 \%$ in 2011. Learner's satisfaction rates increase with e-learning compared to traditional learning, along with perceived ease of use and access, navigation, interactivity, and user-friendly interface design [2]. It was found that below average number of professional courses' teachers in higher education are using e-learning mode whereas only a few non-professional courses' teachers are using e-learning mode. There are three modes of e-learning: online mode, hybrid/blended mode and e-enhancement mode but only e-enhancement mode is being presently used by the professional and non-professional courses' teachers in Indian higher education.

\section{Literature Review}

According to f Laurillard's (2006) research "e-learning as the use of any of the new technologies or 
applications in the service of learning or learner support", and it has been considered as operational definition of e-learning [3]. According to Marc Prensky's research different learning outcomes are best learning through particular types of learning activities. He says that we all learn -a) behaviors through limitation, feedback and practice. b) creatively through playing c) facts through association, drill, memory and questions d)language through imitation, practice and impression e) reasoning through puzzles, problems and examples [4]. These studies focus on the changing era and the implications of E- learning in near future. Also supporting to say that E-earning is the wheel for new innovations

\section{Objective and Research}

The basic objective of this study is to understand the concept of e-learning and to examine the type of E-learning. It also summarizes several opinions regarding the comparison between traditional learning, classroom learning and e-learning. This paper aims to discuss in detail the advantages and disadvantages of both the ways of learning, and tries to give some solutions by considering the advantages of both the systems of learning considering the constraints of the situation. In order to fulfill such objective secondary method is adopted. The secondary data was collected through books, periodicals, journal and published material related E-learning for the study.

\subsection{Education Scenario in India}

The traditional learning system had been used in India and was sustainable for long. But the educational needs are changing and a global education standard is imposing itself and forcing the Indian education system to undergo many changes. The concept of e learning is definitely gaining popularity in the country but at a slow pace as compared to other countries.

The Indian Constitution resolves to provide quality education to all and in an effort to fulfill the educational needs of the country specifically for the diverse societies and cultures of the country the government has chalked out different educational categories: Elementary education, Secondary education, Higher education, Adult education, and Technical and Vocational education is nothing but the development of the whole individual and nurturing the potentials inherent traits. E-learning is a useful medium through which India can attain the goal of reaching the unreached in rural areas, motivating the learners for higher education as well as woman empowerment through their education. In the current super fast era and globalised world, education needs to meet the additional demands of present time such as creating globally competent work force. Due to globalization, the whole world has become a global village. Now, education can be used as a useful tool to raise awareness of environment, peace, culture, social diversity, increased competitiveness and the concept of a global village. In the present world, education is being used as a means of becoming a global citizen. In order to work in this more competitive world, one has to be competent enough to survive. Education gives us that powerful tool by which we can live a life of worthiness. It is only through improving the educational condition of a society that the multi-faceted progress of its people can be guaranteed. E-learning is the best option available to achieve these goals. E-learning is also a powerful medium to improve inclusiveness of education in our country. If an educational institution is committed to give high quality education, it should be built on values and ethics, and be innovative in offering its teaching programmes. E-learning is not a single strand but is multifaceted, covering a wide range of approaches and methods [5].

\subsection{Concept and Aspect of e-Learning}

E-learning is electronic learning, and typically this means using a computer to deliver part, or all of a course whether it's in a school, college, part of training or a full distance learning course. E-Learning is learning utilizing electronic technologies to access educational curriculum outside of a traditional 
classroom. In most cases, it refers to a course, program or degree delivered completely.

Education is what remains after one has forgotten what one has learned in school."

-Albert Einstein.

While Einstein's words may have been intended in good humor, they aptly reflect the fact that effective education is constant and always evolving. In fact, the face of education has experienced a sea change over the decades. Once characterized by the traditional classroom model, education has metamorphosed into learning that is instant, online, self-driven and on the go. The journey of education in India, too, has been dotted with innumerable milestones.

In other words, e-learning can also be described as learning that is delivered online, via the internet, ranging from Distance Education, to computerized electronic learning, online learning, internet learning and many others forms. So e-learning can be defined as courses that are specifically delivered via the internet to somewhere other than the classroom where the professor is teaching. It is interactive learning in which learner can also communicate with teachers, professors or other students in the class. Sometimes it is delivered live; where one can "electronically" raise hand and interact in real time and sometimes it is a lecture that has been prerecorded. Normally, there is a teacher or professor interacting /communicating with learner and grading the participation, assignments and tests. E-Learning has been proven to be a successful method of training and education. It is becoming a way of life for many citizens in our country e.g. farmers education, adult education, pre-primary and primary education as well as in higher education.

\subsection{Formal and Informal e-Learning}

Some forms of e-learning - online education and online training recreate the formal learning experience online. Online education provides adults with limited literacy skills with a safe and patient place to develop basic skills such as reading and mathematical skills. The only factor that separates online training from education is that the skills and knowledge taught via training are expected to be used immediately.

E-learning allows us to explore the potential of informal learning such as Knowledge Management and Electronic Performance Support. Knowledge Management is basically recorded pieces of corporate information such as policies, procedures and product information documents, reports, presentations and proposals expertise, often recorded in the form of documents like lessons learned, stories and case histories and online interaction with colleagues and can also include online chats, discussions and symposia during which participants can exchange information not yet been recorded. Electronic Performance Support (EPS) refers to a work environment on a computer in which performers /learners receive assistance. EPS is used in providing information, training, coaching and monitoring needed for support to learners [6].

\subsection{E-Learning and Literacy in India}

As per Census Report 2011 published by Government of India:

Table 1. Percentage of Literate Population

\begin{tabular}{ccc}
\hline \hline Year & $\begin{array}{c}\text { Literates } \\
\text { (\% of total population) }\end{array}$ & $\begin{array}{c}\text { Illiterates } \\
\text { (\% of total population) }\end{array}$ \\
\hline 2001 & $65 \%$ & $35 \%$ \\
2011 & $74 \%$ & $26 \%$
\end{tabular}

Source: Annual Report 2013-14, published by Ministry of HRD GOI.

The above Table 1 shows that the percentage of literate population in the total population has increased in 2011 , from $65 \%$ to $74 \%$ [7], similarly, the percentage of illiterate population has decreased from $35 \%$ to $26 \%$ in the span of a decade. Still the fact remains that $26 \%$ of India's total population is still illiterate and 
e-learning can prove helpful to reduce the illiteracy as the advancement in technology and communication has made teaching and training possible anywhere, anytime. The Learner can learn anywhere; i.e. outside the boundaries of formal classroom. It will be very effective in case of adult education and training [8]. It is a very powerful medium for pre-primary and primary education as it is in audio visual form and can attract even the school dropouts. It will be very effective in case of adult education and training.

\subsection{Women and e-Learning}

Traditionally women in Indian society suffer from various social and cultural handicaps and it is felt that unless the women are sufficiently empowered, the socio-economic development may be difficult to achieve. Empowering women starts from initial involvement in analyzing their own problems, proposing solutions and consequently taking collective action. Regional networking, social mobilization, changing the attitudes and knowledge of women is really needed to increase the women power. The e-learning strategies can really shape them and can bring it into reality. The e-learning techniques would empower women, create legal awareness, encourage them to take up cases of women and also help the women litigants-learning software would bridge the gap between the laws and their effective implementation in rural and urban areas.

E-learning networking can make links between social and legal organizations concerned with legal issues. For example e-learning networking would establish links between Mahila Mandals, lawyers and courts. This means by having concentrated efforts of e-learning we can bridge the gap between social organizations and legal system, between lower and high court, between rural and urban areas, between senior and junior lawyers and so on [9].

\subsection{E-Learning and Government}

Government can make use of e learning medium in various ways. It can help the government to communicate rules and policies effectively. It can create awareness about various schemes and plans among citizens. It will give people an open platform to communicate or learn. E-learning can manage semi-structured and unstructured information [10]. It can deliver the government agenda. A good e-learning solution can help government in multiple aspects. The Government can provide the Learning Portal around Government Policies, Rules \& Regulations in Public Private Partnership (PPP) model. A government can bring transparency in governance by way of a meaningful education among the people through e-learning. Creating social awareness amongst the citizens, providing information about taxation and laws can also be done in an effective manner. Right now, the Government has done it for the farmers of our country by developing online consultancy for growth of agriculture production using latest technology.

\subsection{E-Learning and Higher Education}

According to a recent study in a global level online learning program, after the United States, India has been reported to have the second highest number of online course enrollments with more than over $1,55,000$ students from the country. Of a total of around 1.2 million students worldwide, $32 \%$ are from the U.S while $15 \%$ are from India. In higher education, there is a growing demand to create a virtual learning environment (VLE) in which all aspects of a course are handled through a consistent user interface throughout the institution. Some of these programmes are initiated in our country and students need to attend orientation sessions in colleges, but the course content is delivered online. Several universities do offer online student support services, such as online advice and registration, e-counseling, online textbook purchase and student newspapers. E-learning has the potential to overcome the non-availability of adequately qualified teachers in rural India [11]. Live online tutoring; streaming videos and virtual classrooms are some of the solutions that e-learning can offer to these problems. While there is no 
substitute for effective and organized classroom teaching, e-learning's is the best option. School drop outs can be taught through e-learning as they feel insulted to go to school again. Computerized Assessment of students' performance becomes easier to the teacher/professor, for the courses where the number of students is large. Physically disabled students can learn at home through e-learning study material [12].

Though e-learning is audio-visual medium of learning, it is not free from limitations. According to another report, India's online education market size is set to grow to $\$ 40$ billion by 2017 from the current $\$ 20$ billion.

It has been observed that a group of people who oppose to the concept of e-learning saying that it is informative and does not impart the knowledge of the subject. On the other hand, some people oppose classroom learning saying that self learning with the help computers and other e-material is always better than classroom learning as it does not motivate for self learning. This is especially true for countries where technical education is expensive, opportunities are limited and economic disparities exist. India has one of the largest education systems in the world with a network of more than 1 million schools and 18,000 higher education institutions. More than half of the country's 1.2 billion population falls in the target market for education and related services. Even Agriculture industry is required to connect with higher education and E-Learning.

\section{Conclusion}

As per our research findings we conclude that the rapid increase in internet connectivity is an important catalyst for the growth of e-learning. A robust internet ecosystem, with a multitude of local and global players, will help online learning make further inroads. In underdeveloped and developing countries, e-learning raises the level of education, literacy and economic development. If the agricultural industry targeted through E-learning, the growth rate will defiantly increase. E- Learning and E-commerce can be developed through proper investigate and plan of action.

It is proved that the developing wave of adaptive learning will help higher education, women, government. E-learning is increasing the percentage of literate population in the total population of India. E-learning plays a vital role in educational development as a wheel of growth in education sector. It is expected that if India and developing countries proceed as joint venture and work mutually on the issue of e-learning, it will be beneficial for the development of educational sector. Through E- learning lot of opportunities can be captured and speedy development will possible. It is expected that if India and Malaysia act as joint venture together work out on this issue for development, it will be beneficial for educational sector.

\section{References}

[1] Sharma, R. C., \& Mishra S. (2013). International Handbook on e-Learning, Vol. 2.

[2] Harden, R. M., \& Hart, I. R. (2002). An international virtual medical school (IVIMEDS): The future for medical education. Medical Teacher, 24, 261-267

[3] Laurillard, D. (2006). E-learning in higher education. Changing Higher Education: The Development of Learning and Teaching, 71-84.

[4] Sing, P. P., \& Sharma, S. (2005). E-Learning New Trends and Innovations (pp. 39). New Delhi: Deep and Deep Publications Pvt. Ltd.

[5] Jaiswal, V. (2013). Current Status of e-learning in Indian higher education: A case study of U.P. Retrieved from the Social Science Research Network (SSRN) website: http://ssrn.com/abstract $=2231910$

[6] Tayebinik, M., \& Puteh, M. (2012). Blended learning or e-learning? International Magazine on Advances in Computer Science and Telecommunications (IMACST), 3(1), 103-110. 
[7] Government of India. (2011). Census Report, 223.

[8] Ministry of Human Resource Development, Government of India. (2014). Annual Report, 2013-2014.

[9] Chandra, S. (2014). E-learning prospects and challenges. International Journal of Research in Finance \& Marketing, 4(10).

[10] Shinde, S. P., \& Deshmukh, V. P. Web-based education in schools: A paradigm shift in India. International Journal of Computer Science \& Informatics (IJCSI), 2(1), 2231-5292.

[11] Yuen, A. H. K. (2010). Blended learning in higher education: An exploration of teaching approaches. Proceeding of the 18th International Conference on Computers in Education.

[12] Schneider, G. P. (2007). E-Commerce Strategy, Technology and Implementation (pp. 55-57). India: Cengage Learning India Pvt. Ltd.

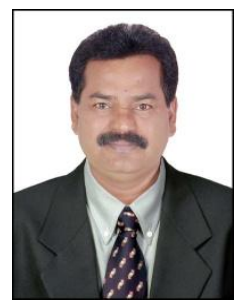

Arun Hari Gaikwad was born in Rumbhodi (Maharashtra ,India ) on $1^{\text {st }}$ June 1965. He is having first class throughout his academic career. He is a vice principal \& the head of the Department of Accountancy in S.N. Art's D.J.M. Commerce and B. N. S. Science College, Sangamner. His teaching experience covers a span of 23 years for the various levels of classes. He is recognized $\mathrm{Ph}$. D. guide and an eminent lecturer having experience of teaching in accountancy auditing and taxation for post-graduate students. He has a vast and rich experience in the field of finance, taxation and co-operation.

He was awarded by G.B. Kulkarni Award for 'Best Teacher' in Commerce by University of Pune. He has attended international conferences in America, Australia and England and also participated in number of Conferences, workshops and seminars, He is a chairman of Board of Studies in Accountancy and Member of Faculty of Commerce of University of Pune. He is a writer of several textbooks for various courses and faculties. He is writer of book Career Opportunities in Commerse. His had research project is on "Working Capital Management in Sugar Factory of Akole \& Sangamner Taluka" under University Grant Commission, Delhi 2008.

Dr. Gaikwad is a life member of All India Commerce Association New Delhi, Member of PUCTO, Professional Organization of Teacher.

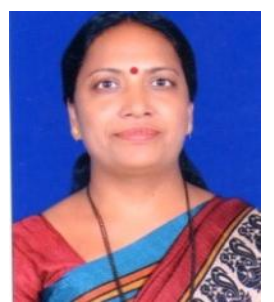

Vrishali Randhir was born in Pune (Maharashtra, India) on $7^{\text {th }}$ March 1971. Her educational background includes the M.Com, Ness Wadia College of Commerce, Pune, 1993; the master of philosophy (M.Phil), Brihan Maharashtra College of Commerce, Pune, 2000; the doctor of philosophy (Ph.D.), Savitribai Phule University of Pune, 2010. Her area of interest is micro finance and micro enterprises.

She is an associated professor working at Ness Wadia College of Commerce. Her work experience is of 22 years. She has presented 25 research papers, which were published in various journals. She had research papers on "Opportunities for agricultural marketing \& e-commerce" at national conference on e-commerce \& IT, Match 2000, Micro Finance: Emerging Horizons, Experience in Pune city, at $60^{\text {th }}$ All India Commerce Conference, Osmania University, Hyderabad. She also participated in Indo China Delegation 2013 as representative of NSS, team LEADER, Ministry of Youth Affairs \& Sports, Govt. of India. She has achieved various awards, the best - three are Nehru Yuva Kendra , Ministry of Youth Affairs \& Sports, Govt. of India: Best Social Worker Award 2012,Intel: Computer Trainer: Star Master Trainer Award-2007; Pune Municipal Corporation : Best Social Worker Award 2003.

Dr Randhir is one secretary of Ness Wadia College of Commerce Students Consumers Co-Op Society ltd, 2002 to 2015, the director of Modern Education Societies Employees Credit Co-Op Society, 2015. 